Abstracta Iranica Abstracta Iranica

Revue bibliographique pour le domaine irano-aryen

Volume 24 | 2003

Comptes rendus des publications de 2001

\title{
« Yādī az Mīrzā Jahāngīr Hēān Šīrāzī ». Kelk, n 126, (1380/2001), pp. 8-10. [Souvenir de Mīrzā Jahāngīr Hูān Šīrāzī]
}

\section{Christophe Balaÿ}

\section{(2) OpenEdition}

Journals

Édition électronique

URL : http://journals.openedition.org/abstractairanica/34805

ISSN : 1961-960X

Éditeur :

CNRS (UMR 7528 Mondes iraniens et indiens), Éditions de l'IFRI

Édition imprimée

Date de publication : 15 mai 2003

ISSN : 0240-8910

\section{Référence électronique}

Christophe Balaÿ, « «Yādī az Mīrzā Jahāngīir Hān Šīrāzī ». Kelk, n 126, (1380/2001), pp. 8-10. [Souvenir de Mīrzā Jahāngīr Hān Šìrāzī] », Abstracta Iranica [En ligne], Volume $24 \mid$ 2003, document 278, mis en ligne le 05 janvier 2010, consulté le 25 septembre 2020. URL : http://journals.openedition.org/ abstractairanica/34805

Ce document a été généré automatiquement le 25 septembre 2020

Tous droits réservés 
« Yādī az Mīrzā Jahāngīr H্̄ān Šìrāzī ». Kelk, nº 126, (1380/2001), pp. 8-10. [Souvenir de Mīrzā Jahāngīr Heān Šīrāzī]

\author{
Christophe Balä̈
}

1 Après Malkom Hูān, brille la figure de Jahāngīr Hูān Šĩrāzī, surnommé « Ṣūr-e esrāfîl » à cause du célèbre journal fondé par le non moins célèbre démocrate Mīrzā Qāsem Hā̄n Tabrīzī, et que Jahāngīr Hुān dirigea pendant la mašrūtiyyat. Le journal claironna courageusement pendant quelques années l'appel à la liberté. De célèbres plumes comme celle d"Alī-Akbar DehHुodā collaborèrent aussi à ce journal, un des plus lus de cette époque. Jahāngīr Hāān Šîāāi fut aussi un des premiers martyrs de la révolution puisqu'il fut assassiné en 1908, lors du coup d'État de Moḥammad-'Alī Šāh qui bombarda le parlement et annula la constitution.

\title{
INDEX
}

Thèmes : 11.1.2. Littérature persane moderne

\section{AUTEURS}

CHRISTOPHE BALA $\ddot{Y}$

IFRI/INALCO - Téhéran/Paris 